\title{
SOCIAL MEDIA IN THE COMMUNICATION BETWEEN THE CITIES OF THE LÓDŹ VOIVODESHIP AND STAKEHOLDERS DURING THE COVID-19 PANDEMIC
}

\author{
Mariusz WOŹNIAKOWSKI \\ University of Łódź, Faculty of Management; mariusz.wozniakowski@uni.lodz.pl, \\ ORCID: 0000-0001-6423-5309
}

Purpose: The aim of this article is to present the basic values of social media in the communication between local government units during the Covid-19 pandemic on the example of the cities in the Łódź voivodeship.

Design/methodology/approach: The research carried out consisted in analyzing the contents of official websites run by the local governments of individual cities of the Łódź Voivodeship in order to check how information about the social networks used (plugin locations) is made available. The active profiles on these websites were reviewed in order to diagnose what content is published. The study was conducted in September 2020. The results were compared to a similar study carried out a year earlier.

Findings: The study has shown that out of 44 analyzed cities in the Lódź Voivodeship, 40 use at least one of the social networking sites. Most often, it is Facebook - 40 cities have their own profile, then YouTube - 19, Instagram and Twitter -7 each. Nine cities have 3 official profiles on various social networks simultaneously, and another 15 cities -2 . No profiles on social networks were found for 5 cities. With regard to the duration of the Covid-19 pandemic, all cities that have actively used social media, have shared content related to the situation mainly through Facebook.

Research limitations/implications: The study did not take into account social networks that were less popular at the time of writing the article (e.g. TikTok, GoldenLine, Pinterest). The objectives of the communication activities of individual cities are unknown. This can be part of further research through in-depth interviews with those promoting their respective cities. It is also possible to extend the research to cities from other voivodeships.

Practical implications: Based on the author's audit of the communication activity of the cities in the Łódź Voivodeship on social networks, this article suggests that the use of social media is an appropriate tactic in city communication, both in terms of promotion and communication in crisis conditions, due to the participatory, interactive, open, and transparent nature of social media.

Originality/value: The publication presents the results of research carried out on the basis of the author's audit of the activity of the cities of the Lódź voivodeship in the social media.

Keywords: social media, city marketing, city promotion, marketing communication.

Category of the paper: Research paper. 


\section{Introduction}

Social groups have been known for a long time, but it was only the virtual space and available internet applications that allowed for their flourishing and application for social, political, and business purposes. Thus, related social groups using social networking sites as organizational and communication platforms have become social networks (PapińskaKacperek, and Polańska, 2016). The constantly improved ICT infrastructure (Information and Communication Technologies) and the increasing use of technology have changed the method of modern communication in the interpersonal and, consequently, also commercial dimension. Public administration could not ignore new solutions that have improved the work of commercial institutions for years. Websites such as Facebook and YouTube have become popular in the everyday lives of citizens, as well as cities (as local government units) in contact with residents via the internet. A developed ICT infrastructure, as well as high internet penetration in society, are prerequisites for ensuring that a large number of citizens are able to use social media and other communication channels on the internet. Both of these factors can be found in the concept of Informational World Cities (Stock, 2011; Mainka, Khveshchanka, and Stocka, 2011). Informational cities consist of two spaces: the space of places and the space of flows. The space of places (i.e. buildings, streets) is dominated by the space of flows (e.g. money, power, information). Such cities are the metropolises of the 21 st century, which are a continuation of Manuel Castells' concept of "Informational Cities" (Castells, 1989). A "World City" is defined by the degree of its "cityness" (Friedmann, 1995; Taylor, 2004; Sassen, 2001), where a dense population is not necessarily a factor that determines whether a city is informational. However, the ICT infrastructure should be developed so that cities can meet the needs of a space typical of the informational city. There are also other terms related to the development of information and communication technologies in relation to cities, such as the digital city (Yigitcanlar, and Han, 2010), smart city (Shapiro, 2006; Hollands, 2008; Jonek-Kowalska, and Wolniak, 2019), knowledge city (Ergazakis, Metaxiotis, and Psarras, 2004) or creative city (Landry, 2005; Florida, 2005).

Therefore, the use of social media when connecting with the environment becomes an important element of the cities' communication strategy. The city's communication, mainly in relation to promotional aspects, has an integrating, stimulating, and competitive function. The integrating function relates to the local community and is aimed at strengthening ties between the people of a given region (during a pandemic, joint actions to overcome the crisis). The stimulating function serves to increase the degree of identification with the examined territory. The last function concerns competition for external funds, investors, tourists, etc. (in the face of the pandemic, presenting oneself as a safe area, where all safety rules are followed). Skillful management of profiles on social networking sites can contribute to the creation of a specific community of residents acting in the name of the common good. 
In addition, it is an opportunity to inform residents non-invasively about the activities of local authorities, which is a valuable source of information and another element for building the informational society (Koszembar-Wiklik, 2013; Woźniakowski, 2015). Therefore, the aim of this article is to present the basic values of social media in the communication of local government units during the Covid-19 pandemic on the example of the cities of the Lódź Voivodeship.

\section{The essence of social media in cities' communication}

A social networking site can be defined as a site targeted at a specific social group or people with similar interests. These websites allow their users to interfere with their content and character quite significantly (Rzepecki, and Hankus-Matuszek, 2009). What is their strength is the fact that the people visiting their profiles are not fully aware of the fact that behind the eyepleasing graphics and catchy texts, under which they click the "Like" button, stands (or at least, should stand) a carefully arranged and meticulously thought-out action plan, which considers the opportunities, threats, and potential benefits that each message brings, that is - a network of deliberately selected facts and conclusions (Woźniakowski, 2015). The skillful use of social networking sites in marketing communication may result in the fact that by sending messages, an organization - a city - can build lasting relationships with the recipients - residents (or other stakeholders, e.g. tourists or investors), which will not stop with the campaign (Rak, 2011). This means that a well-created, credible message will be received positively by the environment, and will also be passed on by the recipients. Moreover, informal communication between recipients turns out to be much more effective than conducting standard promotional activities (Brunk, 2010).

Looking at the communication of cities via social networks, three styles of dialogue with stakeholders can be defined. They were named metaphorically, with the emphasis on their most important features: "advertising post," "hotline," and "discussion club" (Annusewicz, 2019). The first style, "advertising post", is the least participatory form of dialogue. It is characterized by focusing on the implementation of the informational function of the conducted communication and is carried out in the formula of one-way communication, focused on broadcasting and not interested in feedback. The characteristic features of this style are (Annusewicz, 2019):

- a small number of followed accounts of other users, dominated by local government institutions, local politicians, other local government units, and public administration entities;

- no interaction with other users; 
- sharing and liking only the posts by other local government entities, alternatively, media representatives;

- publishing posts of an informative nature only.

The second style, "hotline," is characterized by:

- a relatively large number of followed accounts, although these mainly include, apart from the institutions subordinate to the city, local journalists, activists, and politicians;

- reactive interactions, responding to comments that explicitly mention the username;

- publishing posts mostly of an informative nature.

The last of the communication styles - the most intense and participatory in terms of the essence of communication - is the format metaphorically called a "discussion club". It is characterized by:

- a large number of followed accounts, a significant group of which are residents, persons identifying with the city/municipality;

- proactive (and reactive) interactions consisting in joining the discussions held on a given social networking site, not only when they somehow concern the city, but also when they go beyond the subject of a given city;

- a large number of likes and shares of posts by individuals who are not widely known users of a given website;

- the content of published posts is engaging;

- broad reactions to comments.

\section{Social media used by the cities of the Lódź region}

The research carried out consisted in analyzing the contents of official websites run by the local governments of individual cities of the Łódź Voivodeship in terms of checking how information about the social networking sites used (plugin locations) and the profiles are communicated in these media in order to see what is published and how. In the absence of a link on the website to the most popular social networking site, Facebook, such a profile was searched using the internal search engine on the portal. The study was carried out in two stages: in October 2019 and in 2020. This allowed for observing the changes in the way of communication via social networks caused by the outbreak of the Covid-19 pandemic. Particular attention was paid to what and how was communicated on the city profiles in the prepandemic period, at the time of its announcement (March 2020), and in the period after lifting some of the restrictions (from May 2020). It also indicates the percentage changes with regard to the basic information about the profiles, such as the number of users following a given profile over a year. 
The analysis showed that 40 out of 44 cities in the Łódź Voivodeship use at least one social networking site, compared to 37 a year earlier. Most often it is Facebook - 40 cities have their profile, then YouTube - 19, Instagram and Twitter -7 each. Nine cities have simultaneously 3 official profiles on different websites, another 15-2. Tables 1-4 show which cities have their profiles on individual websites with the number of followers and/or posts and/or views during the same period of 2019 and 2020. In the case of 4 cities, no profiles have been found in the analyzed social networks.

Table 1.

Facebook in the communication of the cities of the Lódź Voivodeship-comparison of basic information - as of October 2019 and 2020

\begin{tabular}{|c|c|c|c|c|c|c|c|}
\hline$\dot{z}$ & $\stackrel{B}{0}$ & 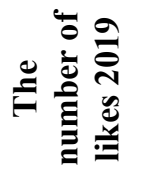 & 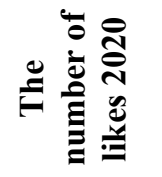 & : & 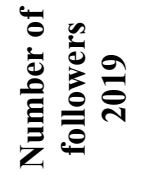 & 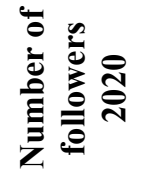 & : \\
\hline 1 & Aleksandrów Łódzki & 9202 & 10659 & $16 \%$ & 9450 & 10990 & $14 \%$ \\
\hline 2 & Bełchatów & 13954 & 15181 & $9 \%$ & 14333 & 15674 & $9 \%$ \\
\hline 3 & Biała Rawska & - & & - & - & & - \\
\hline 4 & Błaszki & 0 & 1069 & - & - & 1117 & - \\
\hline 5 & Brzeziny & 3260 & 3753 & $15 \%$ & 3405 & 4009 & $15 \%$ \\
\hline 6 & Drzewica & 2072 & 2598 & $25 \%$ & 2136 & 2705 & $21 \%$ \\
\hline 7 & Działoszyn & - & - & - & - & - & - \\
\hline 8 & Głowno & 4378 & 5461 & $25 \%$ & 4524 & 5702 & $21 \%$ \\
\hline 9 & Kamieńsk & 32 & 73 & $128 \%$ & 32 & 75 & $57 \%$ \\
\hline 10 & Koluszki & 4480 & 5642 & $26 \%$ & 4631 & 5868 & $21 \%$ \\
\hline 11 & Konstantynów Łódzki & 8700 & 9808 & $13 \%$ & 8879 & 10061 & $12 \%$ \\
\hline 12 & Krośniewice & 975 & 1255 & $29 \%$ & 995 & 1301 & $24 \%$ \\
\hline 13 & Kutno & 12462 & 13160 & $6 \%$ & 12636 & 13447 & $6 \%$ \\
\hline 14 & Lask & 2626 & 3072 & $17 \%$ & 2700 & 3184 & $15 \%$ \\
\hline 15 & Łęczyca & 2870 & 3194 & $11 \%$ & 2922 & 3270 & $11 \%$ \\
\hline 16 & Łowicz & 10851 & 11414 & $5 \%$ & 10983 & 11597 & $5 \%$ \\
\hline 17 & Łódź & 341049 & 359894 & $6 \%$ & 344261 & 368328 & $7 \%$ \\
\hline 18 & Opoczno & 3811 & 4459 & $17 \%$ & 3902 & 4642 & $16 \%$ \\
\hline 19 & Ozorków & - & 2242 & - & - & 2313 & - \\
\hline 20 & Pabianice & 2459 & 2757 & $12 \%$ & 2554 & 2906 & $12 \%$ \\
\hline 21 & Pajęczno & - & 1241 & - & - & 1307 & 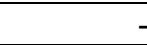 \\
\hline 22 & Piotrków Trybunalski & 8154 & 8680 & $6 \%$ & 8386 & 8971 & $7 \%$ \\
\hline 23 & Poddębice & 553 & 817 & $48 \%$ & 571 & 860 & $34 \%$ \\
\hline 24 & Przedbórz & - & - & - & - & - & - \\
\hline 25 & Radomsko & 4580 & 5199 & $14 \%$ & 4729 & 5413 & $13 \%$ \\
\hline 26 & Rawa Mazowiecka & 3328 & 3975 & $19 \%$ & 3469 & 4173 & $17 \%$ \\
\hline 27 & Rzgów & - & 1141 & - & - & 1195 & 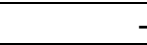 \\
\hline 28 & Sieradz & 4399 & 5683 & $29 \%$ & 4493 & 5907 & $24 \%$ \\
\hline 29 & Skierniewice & 15420 & 16748 & $9 \%$ & 15670 & 17173 & $9 \%$ \\
\hline 30 & Stryków & 1824 & 2702 & $48 \%$ & 1914 & 2876 & $33 \%$ \\
\hline 31 & Sulejów & 2354 & 3305 & $40 \%$ & 2481 & 3475 & $29 \%$ \\
\hline 32 & Szadek & 218 & 533 & $144 \%$ & 229 & 556 & $59 \%$ \\
\hline 33 & Tomaszów Mazowiecki & 11074 & 12876 & $16 \%$ & 11277 & 13288 & $15 \%$ \\
\hline 34 & Tuszyn & - & - & - & - & - & 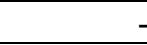 \\
\hline 35 & Uniejów & 5527 & 6155 & $11 \%$ & 5672 & 6354 & $11 \%$ \\
\hline 36 & Warta & 1673 & 2881 & $72 \%$ & 1689 & 2965 & $43 \%$ \\
\hline 37 & Wieluń & 11107 & 11888 & $7 \%$ & 11189 & 12110 & $8 \%$ \\
\hline
\end{tabular}


Cont. table 1.

\begin{tabular}{|l|l|r|r|r|r|r|r|}
\hline 38 & Wieruszów & 3388 & 4598 & $36 \%$ & 3483 & 4768 & $27 \%$ \\
\hline 39 & Wolbórz & 1675 & 1869 & $12 \%$ & 1717 & 1928 & $11 \%$ \\
\hline 40 & Zduńska Wola & 5740 & 6165 & $7 \%$ & 5830 & 6311 & $8 \%$ \\
\hline 41 & Zelów & 1778 & 2417 & $36 \%$ & 1842 & 2538 & $27 \%$ \\
\hline 42 & Zgierz & 11134 & 12627 & $13 \%$ & 11535 & 13219 & $13 \%$ \\
\hline 43 & Złoczew & 4324 & 4923 & $14 \%$ & 4372 & 5021 & $13 \%$ \\
\hline 44 & Żychlin & 3672 & 3899 & $6 \%$ & 3652 & 3944 & $7 \%$ \\
\hline \multicolumn{7}{|c|}{$\mathbf{4 0}$} \\
\hline
\end{tabular}

Source: own research.

Table 2.

Youtube in the communication of the cities of the Eódz' Voivodeship - a comparison of basic information - as of October 2019 and 2020

\begin{tabular}{|c|c|c|c|c|c|c|}
\hline$\dot{\mathbf{z}}$ & 己 & 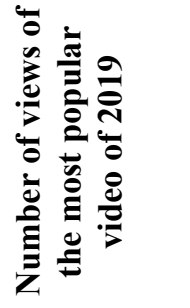 & 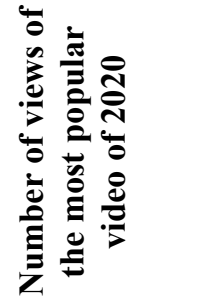 & 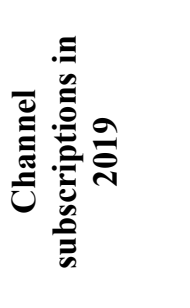 & 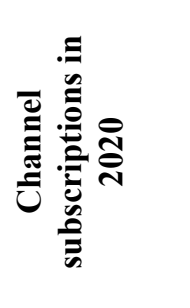 & 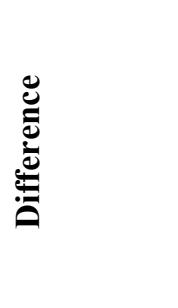 \\
\hline 1 & Aleksandrów Łódzki & 126984 & 13154 & 671 & 896 & $34 \%$ \\
\hline 2 & Bełchatów & 255605 & 273325 & 644 & 693 & $8 \%$ \\
\hline 11 & Konstantynów Łódzki & 1037 & - & 24 & - & $-100 \%$ \\
\hline 15 & Łęczyca & 10016 & 10096 & 65 & 70 & $8 \%$ \\
\hline 18 & Opoczno & 10833 & 12864 & 451 & 695 & $54 \%$ \\
\hline 19 & Ozorków & 9288 & 9769 & 545 & 792 & $45 \%$ \\
\hline 22 & Piotrków Trybunalski & - & 567398 & - & 3750 & - \\
\hline 25 & Radomsko & 18066 & 19735 & 138 & 185 & $34 \%$ \\
\hline 29 & Skierniewice & 6218 & 16823 & 287 & 461 & $61 \%$ \\
\hline 30 & Stryków & 7048 & 7437 & 255 & 305 & $20 \%$ \\
\hline 33 & Tomaszów Mazowiecki & 51174 & 79259 & 387 & 516 & $33 \%$ \\
\hline 35 & Uniejów & 761 & 11506 & 26 & 28 & $8 \%$ \\
\hline 36 & Warta & 1589 & 1958 & 21 & 33 & $57 \%$ \\
\hline 37 & Wieluń & 38157 & 44332 & 136 & 149 & $10 \%$ \\
\hline 38 & Wieruszów & 2892 & 9051 & 47 & 72 & $53 \%$ \\
\hline 39 & Wolbórz & 8588 & 9852 & 20 & 24 & $20 \%$ \\
\hline 40 & Zduńska Wola & 331 & 107565 & 80 & 283 & $254 \%$ \\
\hline 41 & Zelów & 2083 & 2673 & 65 & 105 & $62 \%$ \\
\hline 42 & Zgierz & 17564 & 19399 & 238 & 285 & $20 \%$ \\
\hline 44 & Żychlin & 3764 & 3866 & 46 & 61 & $33 \%$ \\
\hline \multicolumn{2}{|c|}{ Total (number of profiles) 2020} & \multicolumn{5}{|c|}{19} \\
\hline
\end{tabular}

Source: own research. 
Table 3.

Instagram in the communication of the cities of the Lódź Voivodeship - a comparison of basic information - as of October 2019 and 2020

\begin{tabular}{|c|c|c|c|c|c|c|c|}
\hline$\dot{z}$ & $\stackrel{B}{0}$ & 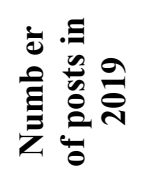 & 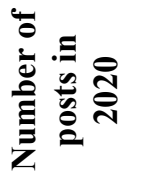 & : & 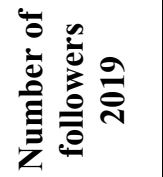 & 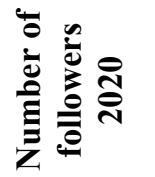 & : \\
\hline 11 & Konstantynów Łódzki & 150 & 1 & $-99 \%$ & 900 & 305 & $-66 \%$ \\
\hline 17 & Łódź & 3596 & 4782 & $33 \%$ & 62800 & 78700 & $25 \%$ \\
\hline 28 & Sieradz & 62 & 94 & $52 \%$ & 481 & 675 & $40 \%$ \\
\hline 29 & Skierniewice & 505 & 773 & $53 \%$ & 2444 & 3185 & $30 \%$ \\
\hline 37 & Wieluń & 73 & 77 & $5 \%$ & 2658 & 2813 & $6 \%$ \\
\hline 38 & Wieruszów & 72 & 79 & $10 \%$ & 266 & 498 & $87 \%$ \\
\hline 43 & Złoczew & 259 & 259 & $0 \%$ & 500 & 512 & $2 \%$ \\
\hline \multicolumn{2}{|c|}{ Total (number of profiles) 2020} & \multicolumn{6}{|c|}{7} \\
\hline
\end{tabular}

Source: own research.

Table 4.

Twitter in the communication of the cities of the Lódź Voivodeship - a comparison of basic information - as of October 2019 and 2020

\begin{tabular}{|c|c|c|c|c|c|c|c|}
\hline$\dot{z}$ & : & 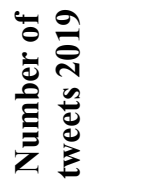 & 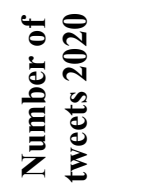 & 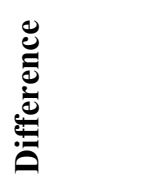 & 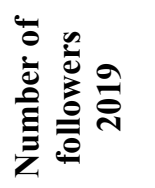 & 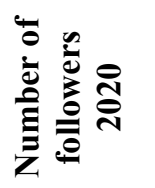 & 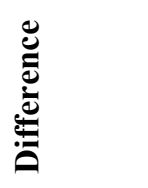 \\
\hline 10 & Koluszki & 22 & 22 & $0 \%$ & 58 & 62 & $7 \%$ \\
\hline 11 & Konstantynów Łódzki & - & 13 & - & & 17 & - \\
\hline 17 & Łódź & 4228 & 5331 & $26 \%$ & 5945 & 8060 & $36 \%$ \\
\hline 25 & Radomsko & 2029 & 2029 & $0 \%$ & 634 & 698 & $10 \%$ \\
\hline 33 & Tomaszów Mazowiecki & 137 & 142 & $4 \%$ & 170 & 220 & $29 \%$ \\
\hline 36 & Warta & 1 & 1 & $0 \%$ & 1 & 1 & $0 \%$ \\
\hline 40 & Zduńska Wola & 359 & 412 & $15 \%$ & 136 & 161 & $18 \%$ \\
\hline \multicolumn{2}{|c|}{ Total (number of profiles) 2020} & & & & & & \\
\hline
\end{tabular}

Source: own research.

Most of the Facebook profiles are up-to-date, and the numbers of followers suggest that an actively run fan-page in communication between the office and the resident has great potential. In many cases, more posts are added daily, or even several times a day. They mostly concern current events in the city and contain numerous photos or videos. The posts take on a different nature in the analyzed period between October 2019 and October 2020. There are 3 stages in communication: the first, before the pandemic; the second, when it broke out and the time of the so-called first lockdown in the period March-April 2020; and the third one, after lifting the restrictions - from May 2020. In the first stage, all published posts can be grouped according to the following categories (Woźniakowski, 2020): 
- for residents (health/social assistance, temporary traffic difficulties, civic budget, reports from events, education);

- free time (cultural and sports events, openings of new restaurants, presentations of places, "behind the scenes" of urban institutions, e.g. showing the work of a tram depot, contests, memes);

- tourism (tourist attractions, history of places - photos and graphics "then and now," festivals);

- investments/renovations/business (public and commercial, new jobs, fairs and conferences).

In the second stage, the published posts took on an official, formal character and concerned only epidemic issues, such as:

- $\quad$ statistics - the number of infected people/number of deaths as a result of a Covid-19 infection, broken down by: the entire country/voivodeship /municipality;

- rules of safety/preventing the spread of the virus;

- information on restrictions introduced by central authorities.

In the third stage, some cities still published mostly formal posts, referring to official government announcements, as in the earlier stage. On the other hand, the second group returned to the original form of communication via Facebook, thus, using generally accepted rules regarding the form of communication (less formal, cutting the distance from the recipient), while still adding posts related to the current epidemic situation,

With regard to the second analyzed website, YouTube, the number of subscribers to each of the channels - profiles is significantly lower than on Facebook. However, this is not a cause for concern for the cities who run the accounts, as in the case of this website, the number of views of individual videos is more important than the number of regular subscribers.

A channel on YouTube is often treated as a kind of Internet TV (e.g. Bełchatów TV, TV Ozorków) or a regional news service (e.g. "Zgierska Przestrzeń," “Tydzień Reporterów," TV Aleksandrów Łódzki). In some cases, the channel mainly reports the sessions of the city council or its subordinate committees (e.g. Zelów, Wieruszów, Stryków).

One year after the previous survey, the biggest problem of local government channels on YouTube is the randomness of published videos and the small number of videos, as well as the lack of new posts. Since the outbreak of the epidemic, only a few posts on YouTube channels have been devoted to this topic. Especially during the summer, videos expressing thanks to the various professional groups involved in fighting the epidemic began to appear.

In the third analyzed social network, Instagram, on 2 profiles - Konstantynów Łódzki and Złoczew's - the activity ceased in February and May 2019, respectively. In the case of the profiles of Sieradz, Wieluń and Wieruszów, new posts appear quite rarely (intervals of several days or even several weeks). In the case of Instagram, the problem for cities is the delivery of relevant content. A specific feature of the website is the visual content, mainly photos, hence 
the publications should have an aesthetic value, or at least, involve professional photo sessions. As a consequence, there is no clearly defined purpose of having an Instagram account. Skierniewice's Instagram profile is dominated by graphics related to cultural and entertainment events, scenery shots, as well as graphics with messages on the state of the epidemic. Compared to this, the profile of Łódź stands out, as it is the only one that is actively run, and the posts (all with the hashtag \#kochamlodz) fit into the nature of the website. The vast majority of posts refer to the presentation of various places in the city, often in an unusual way, thus, expressing quite symbolically the "spirit" of the city, which may encourage both residents and tourists to visit the presented places. With regard to the state of the epidemic, few posts are published and refer to the obligation to cover your nose and mouth, but they are consistent with other graphics and have a decidedly artistic character, e.g. a photo of a mural with the face of Arthur Rubinstein wearing a protective mask.

In the case of the last analyzed website, Twitter, 6 identified city profiles are occasionally updated (Zduńska Wola, Konstantynów Łódzki, Tomaszów Mazowiecki) or its activity has ceased (Koluszki, Radomsko, Warta). The only exception is the profile of Łódź, which is updated on a regular basis, sometimes several tweets are added a day. Most of them relate to current events in the city, although some encourage people to take up activity (including searching for more detailed news) on other websites, mainly on Facebook. Concept-wise, the tweets fit into the nature of the website, which was created to publish short messages that refer the reader to the full content published on other websites.

Compared to the analogous analysis of the use of social networking sites by cities, carried out in 2019, it should be noted that the errors that appeared in these communication channels have not been eliminated. The first oversight is often the wrong placement of social networking plugins in the structure of the official website run by the city hall. They should be located in a visible place, preferably in the top bar of the page, or in the bottom menu or page footer. However, it still happens that they are in an inconspicuous place in the structure of the website, that plugins for different profiles are in different places on the website, or they are not present at all, even though the profile exists. Additionally, clicking on the plugin should open the profile on the social network in a new browser tab, and not replace the currently displayed content.

The second mistake is keeping inactive profiles. Sometimes, despite placing the plugin for a social networking site in a visible place on the page, after redirection to the profile, outdated information or no information is shown. In the absence of new content, it makes no sense to have a profile on a social network. It contradicts the basic idea of their functioning, and for a viewer, it may give the impression that nothing worth showing is happening in a given city.

Another problem is the lack of consistency in the message carried out through social networking sites. By adopting a coherent communication strategy with the use of profiles on individual websites, one can achieve a synergy effect, conduct cross-actions, e.g. by encouraging Facebook users to follow an Instagram account, where a competition for 
residents will be announced, etc. Sometimes it appears that random contents are published and the posts feel stilted.

The last, most common mistake (although the above-mentioned ones do not exhaust the topic) is too many profiles in a situation where there is no clear communication strategy using social media. In this case, the principle that less is more is recommended. For example, on the Opoczno website, one can find 3 plugins for 3 different city profiles on Facebook. The first is "Opoczno as the capital of the oberek," the second is associated with the Ceramic Tile Festival, and the last, the actual municipality. It seems that one would suffice, particularly given that in the case of the first two profiles, publications are quite rare (Woźniakowski, 2020).

\section{Summary}

On the basis of changes in interpersonal communication, communication between the office and the resident (or other stakeholders: investors, tourists, etc.) is constantly evolving. Various types of innovations introduced in this area may temporarily improve the communication process or even revolutionize it, as was the case with the internet (Woźniakowski, 2015) and the subsequent emergence of social media.

Summarizing the methods of communication of the cities in the Lódź Voivodeship on social networks, it should be stated that despite nearly two decades of their widespread use by people and numerous organizations, a significant part of city profiles is run as if their administrators were taking their first steps in the social marketing environment. The capital of the region stands out among all the analyzed cities, and its activities can be a point of reference for them. It cannot be said that the promotional budget of a large city is certainly disproportionately high in relation to other cities in the region, as maintaining a profile on a social network can be a relatively low-cost communication tool. It is mainly about the division of duties and competence of the appropriate people in the office coordinating activities in social media, or employing a suitable external entity. To ensure the effectiveness of communication activities employing social media, it is necessary to have an appropriate strategy in this area for all channels. In many cases, not having it will produce a sense of chaos and randomness in the contents posted. The epidemic only confirmed this state of affairs. While drastically shifting the tone of communication to more definitively formal in the first phase of the threat is understandable - considering that it was a completely new situation for everyone - it seems incomprehensible to continue this method of communication once the residents have become accustomed to the new situation; formal communication through social media is essentially a contradiction of their original idea, which is based on direct and informal communication. 


\section{References}

1. Brunk, K.H. (2010). Reputation building: beyond our control? Inferences in consumers' ethical perception formation. Journal of Consumer Behaviour, No. July-August, p. 278.

2. Castells, M. (1989). The Informational City. Information Technology, Economic Restructuring, and the Urban-Regional Process. Oxford, UK: Basil Blackwell; Cambridge, MA.

3. Ergazakis, K., Metaxiotis, K., and Psarras, J. (2004). Towards knowledge cities: Conceptual analysis and success stories, Journal of Knowledge Management, 8(5), pp. 5-15.

4. Florida, R.L. (2005). Cities and the Creative Class. New York, NY: Routledge.

5. Friedmann, J. (1995). Where we stand. A decade of world city research. In: P. Knox and P. Taylor (Eds.), World Cities in a World-System (pp. 21-47). Cambridge, UK: Cambridge University Press; New York.

6. Hollands, R.G. (2008). Will the real smart city please stand up? City, 12(3), pp. 303-320.

7. Landry, C. (2000). The Creative City: A Toolkit for Urban Innovators. London, UK: Earthscan.

8. Łebkowski, M. (2009). E-wizerunek. Internet jako narzędzie kreowania image’u w biznesie. Gliwice: Helion.

9. Mainka, A., Khveshchanka, S., and Stock, W.G. (2011.06.30). Dimensions of informational city research. Digital Cities 7 - Real World Experiences. International Workshop at C\&T 2011, Brisbane, Australia.

10. Podlaski, A. (2011). Marketing społecznościowy. Tajniki skutecznej promocji w social media. Gliwice: Helion.

11. Rak, A. (2011). Facebook, przyjaciel czy wróg przedsiębiorstwa. Zeszyty Naukowe UE w Poznaniu, No 209, p. 99.

12. Rzepecki, J., and Hankus-Matuszek, G. (2009). Wymagający użytkownik - bezcenny. Marketing w praktyce, No. 8, p. 36.

13. Sassen, S. (2001). The Global City. New York, London, Tokyo. Princeton, NJ: Princeton Univ. Press.

14. Shapiro, J.M. (2006). Smart cities. Quality of life, productivity, and the growth effects of human capital. Review of Economics and Statistics, 88(2), pp. 324-335.

15. Stock, W.G. (2011). Informational cities: Analysis and construction of cities in the knowledge society. Journal of the American Society for Information Science and Technology, 62(5), pp. 963-986.

16. Taylor, P.J. (2004). World City Network. A Global Urban Analysis. London: Routledge.

17. Woźniakowski, M. (2015). Media społecznościowe w komunikacji samorządów terytorialnych. Przykład regionu świętokrzyskiego, Studia $i$ Materiały "Miscellanea Oeconomicae" (2081-2345), nr 4/I, pp. 291-303. 
18. Woźniakowski, M. (2020). Social media used by local governments of the Łódź Voivodeship. Zeszyty Naukowe. Organizacja i Zarządzanie, Politechnika Ślaska (16413466), $n$ r 146, pp. 533-542.

19. Yigitcanlar, T., and Han, H.J. (2010). Urban telecommunications network. Technology convergence and urban infrastructure. In: T. Yigitcanlar (Ed.), Sustainable Urban and Regional Infrastructure Development. Technologies, Applications and Management, Information Science Reference (pp. 77-90). Hershey, PA.

20. Żak, K. (2015). Media społecznościowe jako narzędzie budowania relacji przedsiębiorstwa z klientem. Zeszyty Naukowe Uniwersytetu Szczecińskiego, No. 117, p. 310. 